\title{
THE IDEA OF INTERNATIONAL COMMUNITY
}

\section{STARPTAUTISKĀS KOPIENAS IDEJA}

\author{
Edmunds Broks, Dr. iur. \\ Docent, Department of International and EU Law, Faculty of Law, \\ University of Latvia
}

\section{Kopsavilkums}

Raksts ir veltīts starptautiskās kopienas jēdziena izpētei starptautiskajās tiesībās. Raksta sākumā apskatīti jēedzieni "starptautiskā kopiena" un "starptautiskā sabiedrība", to sociologiskā izcelsme un pašreizējā lietošanas prakse. Otrajā nodaḷā analizēts, kā starptautiskās kopienas realizāciju praksē vērtē galvenās starptautisko tiesību skolas (reālisti, internacionālisti un universālisti). Trešajā nodal̦ā apskatītas tendences starptautiskajās tiesībās atzīt kopīgo interešu aizsardzību un secināts, ka pašreizējā attīstības stadijā starptautiskās tiesības piemērotāk ir konceptualizēt tikai kā retorisku, suverēnu veidoto kopienu. Tomēr starptautiskās kopienas jēdziena lietošana ir noderīga un atbalstāma, jo tā veicina kopīgo interešu atzīšanu, kura savukārt 21. gadsimtā ir vitāli nepieciešama, lai izveidotu šo interešu aizsardzības mehānismus.

Keywords: international community, history of international law, theory of international law

Atslēgvārdi: starptautiskā kopiena, starptautisko tiesību vēsture, starptautisko tiesību teorija

\section{What is a community?}

In western philosophical thought, the concept of community was first theorised by German sociologist Ferdinand Tönnies in 1887. In his famous work "Gemeinschaft und Gesellschaft", Tönnies proposed a distinction between community or Gemeinschaft - a small group that is characterised by a sense of togetherness and interdependence, such as a family or neighbourhood, and between society or Gesellschaft - a larger group with a lesser perception of interconnectedness, such as a state. ${ }^{1}$ For Tönnies, members of a community are well aware of the common interest of the group and see themselves as means to secure those interests. On the other hand, members of a society are rather preoccupied with their individual interests and see the social group only as means for achieving their individual goals. ${ }^{2}$

Of course, ideas on forms of human unity, such as those proposed by Tönnies, are not exclusively a product of Western philosophy and run considerably further

\footnotetext{
1 See Tönnies F. Community and Society. Devon: David \& Charles, 2011.

2 Ibid., p. 69.
} 
back than the late $19^{\text {th }}$ century. Most creation myths suppose a profound oneness and interconnectedness of all human beings (or, indeed, all beings). ${ }^{3}$ The same principle of social and moral unity is discernible in major monotheistic religions, such as Judaism, perceiving all humans as children of the Creator and thus being part of one family. The idea of oneness of human society, which ought to manifest itself also in political and legal terms, appears prominently in works of Stoic philosophers. ${ }^{4}$ In medieval Europe, the idea surfaces in perception of Respublica Christiania - a sense of a community of Christian states united by one faith, common values and a need to defend against common enemies. Interestingly enough, ideological unity of this early European "community" based on unity of values and purposes, although appearing within a setting of relatively undeveloped and unsophisticated interstate relations, arguably presents an example of an international system that resembles a community much more than the sovereignty dominated international system that came about after the Westphalian Peace Treaties of $1648 .^{5}$

The concept of international community (or rather society as societas gentium) first enters legal discourse in the period between fifteenth to seventeenth centuries in writings of such scholars as Vitoria, Svarez, Gentili and Grotius. ${ }^{6}$ However, by the beginning of the $21^{\text {st }}$ century the use of the term has become all-pervasive statesmen make appeals to the international community or claim to speak on its behalf, international conferences seek to protect its interests, the Statute of the International Criminal Court proclaims Court's jurisdiction over crimes which are "of concern to the international community as a whole", and even the United Nations Security Council occasionally calls on the "international community". The International Court of Justice has likewise taken on the vocabulary: in Legality of Nuclear Weapons ${ }^{9}$, Tehran Hostages ${ }^{10}$ and the Barcelona Traction ${ }^{11}$, in all of these, the Court refers to the "international community". The term also found its

3 See Leeming D. Creation Myths. Oxford: Oxford University Press, 1994.

${ }^{4}$ See Aurelius M. Meditations. Transl. by R. Hard. Herfordshire: Wordsworth, 1997.

5 The so-called Peace of Westphalia, which ended the Thirty Years War in the Holly Roman Empire and also a war between the Dutch Republic and the Kingdom of Spain, consists of three treaties: two Treaties of Münster of 30 January and 24 October 1648, and the Treaty of Osnabrück 24 October 1648. Available at: http://germanhistorydocs.ghi-dc.org/docpage.cfm?docpage_id=4540 [last viewed on August 28, 2018].

${ }^{6}$ Although scholars like Grotius spoke of societas gentium already in the $17^{\text {th }}$ century, hardly the term can be applied to the $17^{\text {th }}$ century world at large. As Abi-Saab notes in this regard: "Yet this universal community, embracing all humanity, was only a theoretical construct or explanation, a mental image, perceived as a philosophical proposition or a distant horizon, rather than as an existent reality", see Abi-Saab G. Whither the International Community? European Journal of International Law, 1998, Vol. 9, p. 250.

7 Rome Statute of the International Criminal Court, 17 July 1998, UN Doc. A/CONF. 183/9; 37 ILM 1002 (1998), Article 5.

${ }^{8}$ UN Security Council resolution 1973 (2011) On the situation in the Libyan Arab Jamahiriya, 17 March 2011, S/RES/1973(2011). Available at: www.refworld.org/docid/4d885fc42.html [last viewed on September 28, 2018].

9 ICJ: Legality of the Treat or Use of Nuclear Weapons. Advisory opinion, I.C.J. Reports 1996, p. 226.

${ }^{10}$ ICJ: United States Diplomatic and Consular Staff in Tehran (USA v. Iran). Judgment, I.C.J. Reports 1980, p. 3.

11 ICJ: Barcelona Traction, Light and Power Company, (Belgium v. Spain). Judgment, I.C.J. Reports 1970, p. 32, para. 33 . 
way into the Vienna Convention on the Law of Treaties ${ }^{12}$ as well as into the ILC's 2001 Articles on State Responsibility. ${ }^{13}$

However, as has been observed elsewhere: "invoking the international community is a lot easier than defining it."14 Indeed, the term has become so widely used that its meaning is presupposed to be self-evident. But what does "international community" really refer to? One of the most predominant uses of the term in political, scholarly and judicial discourse seems to refer to the sum of predominant actors on international stage - states, international organizations and to lesser extent also other actors, such as international NGOs. Thus, "international community" is merely a convenient collective reference to all those who possess varied degrees legal "personality" on international stage. An important facet of this international community has much to do with articulation of international public opinion. ${ }^{15}$ The difficulty with such an understanding of the concept is that it hardly fits into the substantive meaning of the notion "community". As will be explored later on, a community (in both its sociological meaning and as discussed in legal scholarship) is about an advanced degree of interconnectedness, recognition and actual protection of shared interests and values. One may argue that such a level of interconnectedness and shared interests is present among states of one region in certain specific cases (like the EU), or among NGOs in a specific field (like human rights), or even among all states, but only within a specific area of interests (like peace and security). But an argument that the same applies to the whole multitude of international actors across the whole spectrum of human activity seems questionable. ${ }^{16}$

Another frequent use of "international community" in contemporary discourse implies exclusively the community of states. This meaning of the concept appears specifically in both Vienna Conventions on the Law of Treaties. Article 53 of both conventions, when defining a peremptory norm, explains that it is a norm that is recognized by the international community of States as a whole. This use of the term is present also in many of prominent accounts of international law of the late $20^{\text {th }}$ century. For example, in the $9^{\text {th }}$ edition of Oppenheim's International Law, Jennings and Watts, when discussing universal nature of international law, note that irrespective of differences between states in their political systems or ideologies, international law does not make "any distinctions in the membership of the international community." 17 Such use of "international community", implying

12 Vienna Convention on the Law of Treaties, 23 May 1969, UN Doc. A/Conf.39/27; 1155 UNTS 331.

${ }^{13}$ International Law Commission, Draft Articles on Responsibility of States for Internationally Wrongful Acts, 2001 (A/56/10) (ASR). Yearbook of the International Law Commission, 2001, Vol. II, Part 2, p. 26.

14 Govers A. The Two Powers. Foreign Policy, 2002, Vol. 132, p. 32.

15 The concept of international public opinion in itself is somewhat problematic. In absence of a genuine international public, the so-called international public opinion is articulated by those that claim to be representatives of national publics - governments, groupings of those governments and also international NGOs. The problematic element is that these representatives may not necessarily voice the genuine opinion of national publics. The British military venture in Iraq of 2003 provides a fitting example of governmental policy in stark dissonance to public opinion.

16 Among sceptics of the "international community" see de Visscher C. Theory and Reality in Public International Law. Princeton: Princeton University Press, 1968, p. 94. De Visscher notes: "It is therefore pure illusion to expect from the mere arrangement of inter-State relations the establishment of a community order; this can find a solid foundation only in the development of the true international spirit of men."

17 Jennings R., Watts A. Oppenheim's International Law: Peace. Vol. 1, $9^{\text {th }}$ ed. Oxford: Oxford University Press, 1992, p. 87. 
a community of states, certainly has some validity in a sense that it refers to a relatively small group, thus fitting the sociological meaning of the concept. The designation "community of states" perhaps was even more fitting in 1945 when that community was made up of only about 51 members. However, as will be explored later in this article, the size of a group by itself does not merit a label of a community, if essential characteristics of high degree of interdependence and shared interests are absent. ${ }^{18}$

\section{2. "International community" for realists, internationalists and universalists}

Opinions on whether states recognize their common interests (and accordingly that there is something akin to an international community) are inevitably influenced by philosophical outlooks that one holds about the reality of international relations. The whole multitude of scholarly opinions on this point has been categorized into three basic traditions or schools of philosophic thought. ${ }^{19}$

The first tradition is that of "realists". For this tradition, international relations are all about pursuit of national interest above all else - a struggle for power straight and simple. International system is a kind of jungle where powerful states do as they wish, while "the weak suffer what they must"20. Hans Morgenthau presents an example of a "realist" outlook: "International politics, like all politics is a struggle for power. Whatever the ultimate aims of international politics, power is always the immediate aim." ${ }^{21}$ This ceaseless struggle forces states to do whatever they can to maximize their power at the expense of other competing states. ${ }^{22}$ Thus, international cooperation, according to realists, will take place only as far as it serves self-interest to maximize power. International rules in such a system are only a smoke screen that may be used to subject weaker states or to be violated when a violation would grant a competitive advantage. The true province of law, for realists, is to deal with inconsequential, uncontroversial mundane technicalities - the stuff about which one feels cool and dispassionate. All matters of genuine importance are the province of politics.

On the level of state, rhetoric realism has been out of fashion since the advent of the United Nations Charter and states generally tend to justify their actions on the basis of international law. ${ }^{23}$ In scholarly discourse, the realist tradition somewhat

${ }^{18}$ It must be noted that other more specific uses of the term "international community" appear in scholarly discourse of the "universalist" or "Kantian" strand. Many of these authors argue that international community refers not only to generally recognized subjects of international law, such as states and international organizations, but encompass the whole humanity, with individual as the genuine subject of the international community. See Allott P. Reconstituting Humanity - New International Law. European Journal of International Law, 1992, Vol. 2, p. 219; Cassese A. The Human Dimension of International Law. Selected Papers. Oxford: Oxford University Press, 2008.

19 Bull H. The Anarchical Society: A Study of Order in World Politics. London: Macmillan, 1977, p. 23.

20 Thucydydes, The History of the Peloponnesian War. Transl. W. Smith. London: Jones \& Co, 1831, Book V, Chapter 17.

${ }^{21}$ Morgenthau H. Politics Among Nations. $5^{\text {th }}$ ed. New York: Knopf, 1978, p. 29.

${ }^{22}$ Morgenthau H. Positivism, Functionalism, and International Law. American Journal of International Law, 1940, Vol. 34, p. 260.

${ }^{23}$ Even at the height of its hegemony, the United States still attempted to attire its military venture in Iraq in 2003 as legitimate, claiming existence of weapons of mass destruction to obtain authorising Security 
fell from grace right after the Second World War, just as its leading proponents of 1930s, such as Morgenthau, had fallen from favour of their more liberally minded (and competing) colleagues. ${ }^{24}$ However, with the beginning of the Cold War, "realist" international scholars came back to prominence, emerging under the international relations rather than international law banner. ${ }^{25}$ On the level of state practice, however, occasionally there seems to be very good evidence of workings of a realist outlook. Whenever that happens, marked inconsistency in state rhetoric and conduct becomes apparent. Such inconsistency outlines a dilemma of an applied realism - on the one hand, states (since their paramount interest is to preserve themselves) will go to great length to emphasize importance of territorial integrity, non-intervention and sacrosanctity of sovereignty. While on the other hand, realist policy in actual application does not respect these principles in the least (or any principles for that matter) and will disregard them the moment when that seems to grant an advantage.

A poignant example of this dilemma might was causing intellectual struggles for Russian legal scholars post Crimean annexation. All along they have strongly argued against a right of external self-determination (except for peoples of former colonies), claiming that sovereignty and territorial integrity prevail. ${ }^{26}$ Russian annexation of the Crimea in 2014 on the basis of an alleged exercise of self-determination by Crimeans, which Russia regards as lawful, required the exact opposite - that self-determination prevails over sovereignty and territorial integrity. However, from a realist theory point of view, this inconsistency of arguments only confirms the realist thesis - that rules are nothing but means to be used in the struggle for power. The inconsistency of argument occurs only because on the level of rhetoric Russia claims not to have a realist outlook, whereas in fact it does. Thus, for realists "taking rights seriously" is to miss the point of international relations. The only shared value cherished by all members of a realist system is the survival of the state system itself. Therefore, for realists, talk of the international community, if anything, is a nonsense that may only hide an imperial or some other project.

The second tradition is "internationalist" or "Grotian". As opposed to "realists", "Grotians" believe that states, rather than being immersed in perpetual strife for power, also pursue common interests and goals. Bull further divides "Grotians" into two subgroups, which may be labelled as "Vattelians", and "neo-Grotians". ${ }^{27}$ "Vattelians" hold a view that although international co-operation does occur, the system as a whole is still dominated by individualistic interests of states. Common interests exist only to an extent that they are necessary to maintain stability for states to pursue their individual interests. For "Vattelians" states do participate

Council resolution. See Gray C. From Unity to Polarization: International Law and the Use of Force Against Iraq. European Journal of International Law, 2002, Vol. 13.1, p. 1.

${ }^{24}$ Criticism of realist approach centres on rigidity of assumptions on which the realist theory is based. Namely, that states are identical in their perceptions of international life, regardless of whether they are democracies or dictatorships, and that strife among states is perpetually at a level that states are continuously readying for war. Both of these propositions seem open to doubt.

25 See Wolfers A. Discord and Collaboration: Essays on International Politics. Baltimore: Johns Hopkins University Press, 1962.

26 Лукашук И. Международное право, Общая часть. Москва: Волтерс Клувер, 2001, 280 с.; Ковалев А. А., Черниченко С. В. (ред.). Международное право. 3-е изд. Москва: Проспект, 2008, $58 \mathrm{c}$.

27 Bull H. 1977, p. 310. 
in international organizations, however, those organizations remain a vehicle for channelling and accommodating agendas based on national interest. Bilateralism remains the rule, and order is the core value of the system. The Westphalian system is a clear embodiment of the "Vattelian" outlook. Thus, the whole preCharter classical international law of sovereign equality of nation states fits this conception of an international system.

The second sub-group of "Grotians" are the so-called "neo-Grotians". This view of international relations places emphasis on communitarianism and recognition of common interests. The way to achieve these interests, according to "neo-Grotians", is by cooperating in common institutions. ${ }^{28}$ The international system and international law are perceived as being on their way to becoming a genuine community regulated by international legal order. Bilateralism and unlimited sovereignty eventually are to give way to multilateralism and solidarity. Much of the post-Charter international law, in particular such projects as gradual construction of the international community, have been inspired by "neo-Grotianism". Some of the most prominent international law scholars of the $20^{\text {th }}$ century, such as Friedmann, Lauterpacht and many others are adherents to this conception of inter-state relations.

The final tradition that may be identified is "universalist" or "Kantian". For this strand of thought, international system, although formally comprised of states, in fact is made up of a community of mankind. States merely serve as means to organize international cooperation. Particular emphasis is placed on direct forms of representation (such as via NGOs) and on individuals as true subjects of the international system. It is not uncommon for Kantians to argue for fundamental reinvention of the idea of the international system, for conservative idealist revolution, and even to do away (at least philosophically) with states "those random by-products of the chaos of history, artificial amalgams of lands and tribes [..] [and with governments] some of them no better than criminal conspiracies." 29 Justice and human rights are paramount values of this outlook. Many of the modern international "constitutionalist" scholars are adherents of this school of thought. The possibility of the international community for these scholars is their project - to introduce a new idea of the international community, a community of the whole humanity, which sees rule of law as an inherent part of itself. It is noteworthy that affection for Kantian themes is not limited to scholars only. Dissenting opinions of such judges of the International Court of Justice as Álvarez (in South West Africa ${ }^{30}$ ), Weeramantry (in Legality of the Treat or Use of

28 Zimmern A. Spiritual Values in World Affairs. Oxford: Clarendon Press, 1939.

29 Allott P. The Idealist's Dilemma: Re-Imagining International Society. Published on June 9, 2014. Available at: http://www.ejiltalk.org/the-idealists-dilemma-re-imagining-international-society/ [last viewed on September 15, 2018].

30 See dissenting opinion of Judge Alvarez in International Status of South West Africa. In particular, Álvarez notes: "This society consists not only of States, groups and even associations of States, but also of other international entities. It has an existence and a personality distinct from those of its members. It has its own purposes". International Status of South West Africa. Advisory Opinion, dissenting opinion Judge Alvarez in [1950] I.C.J. Reports, p. 175. 
Nuclear Weapons ${ }^{31}$ ) and Cançado Trindade (in Questions Relating to the Obligation to Prosecute or Extradite ${ }^{32}$ ) all seem to resonate with Kantian themes. ${ }^{33}$

Why are these theoretical outlooks important? It has been argued that whether we are conscious of theory or not, perceptions we form and choices we make on their basis in fact constitute a theory. As noted by Allott: "people speak theory in everything they say and do, every day of their lives, even if they don't know what the theory is, or where it came from." ${ }^{4}$ Becoming aware of a theory shines a light on assumptions made about the phenomena we encounter. Knowing the theory identifies its elements with focused clarity and makes one realize connections and causes. Therefore, theorising may be a beneficial exercise. However, being aware of a theory also seems to work the other way around. A theory may easily become an intellectual identity of "I'm a realist". Such taking up of an intellectual identity inadvertently conditions perceptions of legal phenomena, which, in turn, lead to automated judgments and loss of the quality of investigation and insight. Therefore, it seems best to employ the above outlined theories, but only in a way that is open: if one feels strongly universalist, perhaps it would be useful to acknowledge some truth of what realists are saying. If one feels strongly "legal", despising indeterminacy of political argument, it may be a good idea to read more on international relations. As Koskenniemi has observed on usefulness and at the same time limitations of theoretical approaches: "[r]esearch serves practice by producing critical reflection and self-awareness in acting lawyers. But it fails to provide answers to problems on which practising lawyers are requested to give advice." 35

\section{A rhetorical community of sovereigns?}

Classical international law, as it emerged after the Peace of Westphalia, was in essence a law of coexistence. The corresponding philosophical outlook that supports the law of coexistence approach is "Vatellian". Thus, classical

31 ICJ: Legality of the Treat or Use of Nuclear Weapons. Advisory opinion [1996] I.C.J. Reports p. 226. Weeramantry observes that: “The Charter's very first words are "We, the peoples of the United Nations" - thereby showing that all that ensues is the will of the peoples of the world. Their collective will and desire is the very source of the United Nations Charter and that truth should never be permitted to recede from view. In the matter before the Court, the peoples of the world have a vital interest, and global public opinion has an important influence on the development of the principles of public international law." See Judge Weeramantry dissenting opinion, p. 190.

32 ICJ Questions Relating to the Obligation to Prosecute or Extradite (Belgium v. Senegal). Merits, [2012] I.C.J. Reports. 422. Cançado Trindade notes: "The consolidation of erga omnes obligations of protection, ensuing from the imperative norms of international law, in my understanding overcomes the pattern erected in the past upon the autonomy of the will of the State, which can no longer be invoked or pursued in view of the existence of norms of jus cogens. These latter transcend the law of treaties, and encompass nowadays the domain of State responsibility. Those obligations, in their turn, clearly transcend the individual consent of States, heralding the advent of the international legal order of our times, committed to the prevalence of superior common values, in the ongoing construction of the international law for humankind." See Judge Cançado Trindade dissenting opinion, para. 71, p. 441.

${ }^{33}$ For a detailed discussion of universalist approaches in the practice of the ICJ see Gordon G. Innate Cosmopolitan Dialectics at the ICJ: Changing Perceptions of International Community, the Role of the Court, and the Legacy of Judge Álvarez. Leiden Journal of International Law, 2014, Vol. 27, p. 309.

34 Allott P. 2014.

35 Koskenniemi M. New Approaches to International Law. In: Kennedy D., Tennant C. (eds.). New Approaches to International Law: A Bibliography. Harvard International Law Journal, 1994, Vol. 35, No. 2, p. 427. 
international law is far from a model in which states work for the good of common goals, but rather pursue individualist interests without much actual regard for benefits that may result from cooperation.

However, the law of cooperation has been gradually growing - starting from the $19^{\text {th }}$ century in specialized fields such as transport and communications and steadily creeping into ever new areas of human activity. ${ }^{36}$ This gradual expansion continued also in the $20^{\text {th }}$ century until the adoption of the UN Charter, which attempted to drastically reshape the landscape of international law. ${ }^{37}$ All the purposes of the UN listed in Article 1 of the UN Charter call for multilateral cooperation for the good of shared goals. Also most of the principles enumerated in Article 2 (apart from the first one), such as peaceful settlement of disputes (Article 2(3)), provision of assistance to the UN (Article 2(5)) and, in particular, Article 2 (6) obliging the UN to ensure that also non-members comply with these principles, all seem to belong to the law of cooperation approach. Even more importantly, the overall scheme of the Charter (considering the preamble which defines the essential aspiration of the organization - "to save succeeding generations from the scourge of war"; also rules aimed at pacific settlement of disputes via cooperation in chapter VI and extensive powers of the Security Council under chapter VII), all demonstrate that the UN Charter is constructed around the paramount common interest - safeguarding of international peace. A system that aims to reach a shared goal and provides for institutions endowed with powers to reach that goal, are a strong indication that the system, at least partly, is based on the law of cooperation.

Whether the above findings are sufficient to claim that the Charter indeed fundamentally transformed international law from the law of coexistence to the law of cooperation is another question. As we turn from Purposes of Article 1 to Principles of Article 2, a somewhat different view emerges. The first among Article 2 principles is that "the Organization is based on the principle of sovereign equality". Thus, although heralding a new era for international law, the Charter also proclaims both principles which are at the heart of the law of coexistence (sovereignty and equality) as the foundational principles of the Charter system. Likewise, the institutional mechanisms to achieve the lofty goals of cooperation are overwhelmingly absent from the Charter. Principal organs of the UN, apart from the Security Council and the International Court of Justice, are in their essence forums for inter-state deliberations. Also, the Charter itself does not provide for substantive rules in any of the areas where it aspires to promote cooperation - be it in economics, human rights or culture. The principal organs, apart from the Secretariat, are not supranational. Thus, as well demonstrated by the selectiveness in the practice of the Security Council, UN organs most often will function as means by which states pursue individualistic interests, rather than the interest of the whole international community. Therefore, the law of cooperation seems strong predominantly on the level of legal rhetoric, rather than on the level of actual institutions and policies.

${ }^{36}$ International treaties and corresponding international organizations emerged in areas such as public health (the International Office of Public Health, now the World Health Organization, was established in 1903) and agriculture (International Institute for Agriculture, now the Food and Agriculture Organization, established in 1905).

${ }^{37}$ Fassbender B. The United Nations Charter as the Constitution of the International Community. Columbia Journal of Transnational Law, 1998, Vol. 36, p. 529. 
However, the above analysis has a few exceptions. The most notable among those belongs to the field of international peace and security. Here, the Charter provides not only for a shared goal, but also an institution with actual powers. It also provides for substantive norms - although defined in very general terms, the prohibition of use of force, the exception of self-defence, and the powers of the Security Council under Chapter VII provide a minimalistic framework which nonetheless, if accompanied by political will, may be fully operational in safeguarding the shared interest of maintaining international peace and security. In limited ways also other UN organs occasionally act in accordance with the law of cooperation approach as organs of a genuine community. The UN General Assembly may (and occasionally does) perform a very important function of collective legitimation. ${ }^{38}$ The General Assembly may adopt resolutions on any matter, thereby expressing the viewpoint of the whole community of states, as in the case of condemnation of Russia's annexation of Crimea. ${ }^{39}$ Although legally non-binding, political weight of collective legitimation (and thus also impact on state conduct) may be considerable.

From the sketchy outline above, we may conclude that international law is a mix of the law of coexistence and the law of cooperation. Accordingly, following the earlier proposed thesis that the more the law leans towards cooperation, the more likely it is that a community exists, we may conclude that international law displays signs of communitarianism, while at the same time holding on to sovereign equality as a foundational block of the international legal order. Therefore, it is suggested that at present we are left with a "rhetoric community of sovereigns", rather than an actual community.

\section{Conclusions}

1. The concept of the international community is vague and therefore open to various interpretations. Even more importantly, the concept has much to do with power and legitimacy and thus is inevitably susceptible to abuse. Its ambiguous content may thus be of more service to political rhetoric than to courts of law. Likewise, having an idea of an international community in itself may not necessarily be an outright positive development. Whenever a reference to the international community is made (if, for instance, force is used on its behalf), a question arises - whose community is it? Who may speak and act on its behalf? Who dictates the terms on which this community operates? Is it truly an international community (on guard of supranational interests) or rather an imperial project clothing power in a mantel of legitimacy?

2. The present-day scholarly discourse on the international community (at least most of it) runs on an assumption that the present international system is indeed a community as it is defined in sociological terms and in classifications of international affairs. Within this meaning, the concept of the international community refers to a relationship in which members of a group recognize goals and values that are not merely in their own individualistic interests,

${ }^{38}$ Claude I. Collective Legitimization as a Political Function of the United Nations. International Organization, 1966, Vol. 20, p. 367.

${ }^{39}$ UN General Assembly, Resolution on Territorial Integrity of Ukraine, March 27, 2014. UN Doc. A/68/L.39. 
but rather benefit the whole group and are therefore shared by the whole group. Also these shared interests are of such nature that they can be well accomplished only if most of the members of the group are genuinely concerned with protection of the shared interest. Thus, "community" first and foremost denotes a sense of unity, togetherness and interdependence - a structure, in which fundamental shared interests are recognized as standing above individualistic interests.

3. However, even a brief overview of fundamental tenets of international law (e.g., the UN Charter) indicate that such labelling of the current international system has more to do with an aspiration to have a community, rather than actual existence of an interdependent group which is aware of common values and shared goals and actually engages in their realisation. That being said, it must also be acknowledged that forms of communitarianism are also very much present, although they may not be of universal membership or encompassing all fields of inter-state activity. Consequently, there seems to be some sense of a community at least with regard to maintenance of international peace and security. There also seem to be regional arrangements, such as the EU, that would genuinely merit a label of a community. It is therefore suggested that it is more appropriate to talk about multiple communities existing within the international system, e.g., a community of peace and security, a community of international trade or a regional community of human rights. It is a system of multiple parallel and occasionally overlapping communities on different subject matters. An assertion that states presently form an international community which continuously encompasses all aspects of inter-state relations indeed would be an exaggeration, since many areas of international relations are dominated by individualistic rather than common interests. Whereas on other subject matters, such as climate change, preservation of peace or management of global commons, all actors will, at least to a certain extent, recognize their shared interest in protecting interests of the whole group (although they may not necessarily act in accordance with those interests).

4. Therefore, it is suggested that the universal international community on all subject matters of international life is a rhetorical community only an aspiration that may nonetheless facilitate evolution of a genuine allencompassing international community. This designation, however, does not make shared interests and common objectives of states any less real. Although the present day international "community" in sociological terms provided by Tönnies is more of a society than a community, the use of the concept is nevertheless to be encouraged on all levels of discourse including judicial and legislative, as it facilitates recognition of shared interests, which in turn is a precondition for a much needed agreement on mechanisms for protection of those interests. 